\title{
Collaborative Work in the Prewriting Stage
}

\author{
Juliana Wijaya
}

\begin{abstract}
This paper explores the notion of collaborative work in the prewriting stage. Several collaborative prewriting activities are presented to encourage students to optimize their peers' help in obtaining ideas to write. Those activities will ultimately help students get interesting ideas to write and develop them into dynamic writing.
\end{abstract}

Keywords: collaborative work, prewriting, dynamic writing, brainstorming, chained information, clustering, trategic questioning, information gathering, buddy journals

Helping students get and develop ideas is an integral aspect of teaching writing. Many researchers have examined both teacher's written and oral responses (such as in one-to-one teacher-student writing conferences) to student writing and also students' responses toward their peers' writing. Thus, students' working together (collaborative work) in giving feedback either in the development of ideas and editing process is very common. In this paper, however, I would like to explore how students can help each other get ideas in the prewriting stage. When I was teaching Writing 1 (the very beginning level of writing classes) at Petra Christian University, Surabaya, my students often told me that they could not write because they did not have interesting ideas to write. When students are short of ideas, they tend to be less confident in writing. That is why; getting idea is a very crucial process in the prewriting stage that I would like to address.

In this paper, I would discuss the use of collaborative work in the prewriting stage to help students get interesting ideas to write, then develop those ideas into what Ikeguchi (1997) calls dynamic writing. Dynamic writing is whenever students' writing is not just a copy of model writing. It really expresses students' ideas that are richly developed and elaborated and finally meets audiences' expectation.

\section{Writing: A Process and Collaborative Work}

Before we (writing teachers) guide our students to the prewriting stage, we have to motivate them. One way to motivate our students is to point out to them that writing is a process. In the process, a writer goes through the intertwining stages of prewriting, writing and revision. In fact, as writers, students can discover and rediscover their ideas as they attempt to put meaning into prose. Students have chances to develop workable strategies for getting started such as finding topics, generating writing ideas, focusing, planning content and organization. They have chances for drafting, i.e. working through multiple drafts, for revising such as deleting, adding, reorganizing and modifying. They also have chances for editing such as working out problems with word choice, grammar and mechanics, and sentence structure (Reid, 1993). 
Writing means hard work: it takes time and effort. Competent writers do not produce final texts with their first attempt; instead they find that writing is a long and sometimes painful process, in which the final text emerges through successive drafts. This painful process is recognized as process approach which involves a number of interesting classroom techniques, including conferencing which aims to encourage writers to talk about their initial drafts with the teacher or with fellow students. This approach encourages collaborative group work between learners as a way of enhancing motivation and developing positive attitude towards writing (Nunan, 1991).

Writing itself is inherently cooperative. It is a relationship between writer and reader. Usually the writer has to imagine a reader, but cooperative writing provides each writer with a reader and makes the writing task more realistic and more interactive (Hamp-Lyons and Heasly, 1987). Interaction among students gives them chances to negotiate meaning and allows them to decide for themselves what they want to say and how they want to say it (Gebhard, 1996). The opportunities for collaborative learning in the ESL writing classroom include small group work for idea-generation, cooperative work for gathering and organizing material, peer review and advice, and the presence of authentic audience (other than the teacher) for the writer (Reid, 1993).

With those in mind, I organized several activities around the idea of classroom community; from start-up or warm up activities to prewriting activities that raise students' awareness concerning audiences' expectation. Those activities will allow students to learn about the organizational patterns of academic English writing. However, we also need to remind our students as they collaborate with their peers, and as they make revision choices, they also need to own their work and to remain connected to their drafts. Writers unaccustomed to the writing group process are too often willing to relinquish their own intentions for their drafts in order to accommodate the views or the responses of their readers (Reed, 1995).

\section{Prewriting Activities}

The first activity that can be done collaboratively in the prewriting stage can be in the form of brainstorming. In brainstorming, the teacher or students introduce a topic. After that, all of the students call out ideas associated with the topic while the teacher (or a student or two) writes the ideas on the board. Although there is no right or wrong association in this activity, some EFL/ESL students might shy away from calling out their ideas. If that happens, this collaborative brainstorming would be more effective if done first in small groups melding to include the entire class. In small groups, students can also brainstorm in the activity called 'Chained Information' (Gibson, 1996), in which a student writes an association of the topic of interest on a piece a paper, then he or she gives the paper to the next student in the group who adds another association until all of the students in the group have contributed associations. After that, in groups, they choose the next relevant associations to elaborate.

Similar to brainstorming is an activity called 'Clustering' or word mapping (Gebhard, 1996), in which students' associations are clustered together and stem off of the central word. In other words, using a key word placed in the center of a page (or board), students jot down free associations related to the word (clustering similar words) the other students in the group give.

Another collaborative activity in the prewriting stage is peer interview. I developed a prewriting activity called 'Know Yourself More', which utilizes peer interview to make 
students help each other in exploration of ideas. The ultimate goal of this activity is to have students to write about themselves. First of all, I ask the students to prepare a list of interesting questions they will ask to know more about the other students. Then I pair them with the students they do not know well. Curiosity will drive the students to have interesting questions. We can also guide our students to make the questions interesting. After the questions are ready, the students interview their peers. While interviewing, they write down their partners' answers. Afterwards, they give the notes to their partners they have just interviewed. Finally, they use those notes to help them find ideas to write about themselves. Usually when we ask our students to write about themselves, they are quite reluctant because they think they do not have anything interesting about themselves to write. However, when they read their friends' notes, they will be amazed to see how much, in fact, they can write about themselves. The questions the students prepare to ask their partners can also be useful for expansion of their original ideas. In that way, the students will benefit much from this peer interview. This peer-interview activity can also be used to get more interesting ideas in other personal narratives and descriptive writings.

The next prewriting activity, 'Strategic Questioning', (Gebhard, 1996) can also be done in a collaborative way. In this activity, students go through a set of questions designed to guide their writing such as:

- What do you want to write about?

- What is your goal?

- What do you know about this topic?

- What do you need to find out?

- What interests you or surprises you about this topic?

- Who might want to read what you are about to write?

Students then, can be asked to make their own strategic questions with their peers, and interview each other.

Another kind of collaborative activities students can have is information gathering. In this activity, students work in groups to find more information with regards to the topics of interest. Together, they can go to the library to collect data or they can interview people on the streets. This is, in fact, group writing on appropriate topics that can include cultural events, schools and holidays. After that, they can write about similar topics individually.

Besides conducting previously mentioned prewriting activities, students can also have collaborative warm-up activities. These kinds of activities will probably not directly affect students' writing, but they will help students feel at ease in expressing their ideas and build communal bonds. Dialogue journals (written conversation between two or more people), which usually have teacher and student interaction, in this collaborative prewriting stage, will have student and student interaction instead. We can call this 'buddy journals' in which students communicate with each other through journals. They can share interests, problems, tastes without worrying about status or about pleasing the teacher or taking his or her time. These journals can be done in a larger scale like in groups, so they have group journals or class journals. Many writing teachers call these community journals. Teachers can sometimes give overall comments to these journals. Which journal teachers choose depends on the atmosphere of the class in which teaching and learning take place. Implicit in this classroom climate is the concept of community, in which students help each other as much as possible (Hairston, 1986). The collaborative prewriting activities presented here will hopefully allow 
students to obtain interesting ideas, express themselves meaningfully and develop their dynamic writing.

\section{Conclusion}

Once students have interesting ideas and know how to develop them, they can write better. That is why getting ideas and developing them are very crucial issues that need to be addressed continuously. Some people are born writers. They really have the talent to write, and abundant of great ideas naturally flood them. Others have to struggle to get ideas, but it does not mean they cannot be good writers. They can get ideas through observations, reading, as well as collaborative work in the prewriting stage.

Collaborative work in the prewriting stage helps students get interesting ideas and develop them into dynamic writing. Collaborative work also raises students' awareness concerning audience's expectation, and allows ESL/EFL students to learn about the organizational patterns of academic English writing. The pedagogical generalization that emerges from this study is that writing teachers can optimally use collaborative activities throughout students' writing process including prewriting.

\section{References}

Gebhard, G. (1996). Teaching English as a foreign or second Language: A self development and methodology guides. Michigan: The University of Michigan Press.

Gibson, Bob. (1996). A peer review activity for essay organization. The Internet TESL Journal 2.

Hairston, M. (1986). On not being a composition slave. In C. W. Bridges (Ed.), Training the new teacher of college composition (pp. 117-124). Urbana: NTCE.

Hamp-Lyons. L. \& Heasley, B. (1987). Study writing. Cambridge: Cambridge University Press.

Ikeguchi, B. (1997). Teaching integrated writing skills. The Internet TESL Journal, 3 (3).

Nunan, D. (1991). Language teaching methodology: A textbook for teachers. Herdfordshire: Prentice Hall.

Reed, J. (1995). Making room the self in writing groups. The Writing Instructor, Spring.

Reid, J. M. (1993). Teaching ESL Writing. New Jersey: Regents/Prentice Hall. 